\title{
CORPORATE BANKRUPTCY AND INSOLVENCY PREDICTION MODEL
}

\author{
Alina Daniela VODA (D)1, Gabriela DOBROTĂ (D)2*, \\ Diana Mihaela ȚÎRCĂ (D)2, Dănuț Dumitru DUMITRAȘCU (D) ${ }^{3}$, \\ Dan DOBROTĂ ${ }^{3}$
}

\author{
${ }^{1}$ Faculty of Economics, Lucian Blaga University of Sibiu, Sibiu, Romania \\ ${ }^{2}$ Faculty of Economics, Constantin Brâncusi University of Targu-Jiu, Targu-Jiu, Romania \\ 3"Hermann Oberth" Engineering Faculty, Lucian Blaga University of Sibiu, Sibiu, Romania
}

Received 01 November 2020; accepted 25 April 2021

\begin{abstract}
In any competitive economy, the risk of bankruptcy is pervasive. The research aims to contribute in improving the predictive power of bankruptcy and insolvency risk among companies by introducing new methods of processing and validation. This paper investigates the extensive application of the $\mathrm{Z}$ score model for predicting the economic-financial stability of Romanian companies in the manufacturing and extractive industries. A list of 37 financial indicators determined on the basis of the balance sheet data of 80 companies for the period 2015-2018 was used. Stepwise Least Squares Estimation through the Forward method allowed the identification of the most relevant ones. Canonical discriminant analysis and sensitivity analyzes were introduced to test the predictive power of the model. The new model identified allows both the prediction of bankruptcy and insolvency risk. This study contributes to the literature by testing variables in relation to financial difficulties and by including other classification information. The robustness of the determined canonical discriminant function was verified by testing the model on two other samples.
\end{abstract}

Keywords: bankruptcy, insolvency, risk, multiple discriminant analysis, prediction model.

JEL Classification: C53, G32, G33, O16.

\section{Introduction}

Competitive economic environment is constantly subject to multiple risks, which requires the application of rigorous principles for their management. Unfortunately, more companies have financial difficulties. Both faulty managerial decisions and fiscal pressure or competition increases lead these businesses to the verge of bankruptcy. In addition, changes in the business environment as a result of entering new markets or restructuring the economy can lead to

*Corresponding author. E-mail: gabriela.dobrota@ulbsibiu.ro

Copyright $\odot 2021$ The Author(s). Published by Vilnius Gediminas Technical University

This is an Open Access article distributed under the terms of the Creative Commons Attribution License (http://creativecommons. org/licenses/by/4.0/), which permits unrestricted use, distribution, and reproduction in any medium, provided the original author and source are credited. 
corporate bankruptcy (Garškienė \& Garškaitè, 2004). Also, loss of capital, inability to secure new capital, and high debt or disputes with a particular creditor can be causes of bankruptcy (Levratto, 2013). Risk forecasting can economically recover a business whose continuity is threatened. The risk of bankruptcy occurs when a company cannot pay its debts based on both endogenous causes, but also exogenous causes. However, it is not possible to talk about the existence of a bankruptcy risk of a business in the absence of a financial-accounting diagnosis to determine the state of insolvency, recognized as that state of the patrimony of an entity characterized by insufficient funds for the payment of determined, liquid and matured debts. Indicators specific to liquidity and financial solvency are essential elements in identifying financial problems at the level of the economic entity, providing clues about the ability of the company to pay due tax obligations, the extent to which equity can cover long-term debt, but also about the financial resources currently available.

The risk of bankruptcy cannot be eliminated but it can be identified before it occurs. The causes that lead companies to bankruptcy are numerous, with negative effects in terms of ability to pay. There was a major interest in predicting bankruptcy several years before it manifested itself. The accounting methods to identify the risk of bankruptcy offer the possibility of a limited interpretation in time and space. Banking methods are the most widely used because they allow the identification of the vulnerabilities of a business based on the use of score-type function. These methods make it possible to predict the instability of a business and classify it according to the risk area in which it is located.

The most famous bankruptcy risk-scoring method was developed by Altman (1968). The initial model was built on two groups of 33 companies each, in the manufacturing field. By using multiple discriminant analysis (MDA), Altman determined a set of observations for solvent and insolvent companies, but also a series of financial rates. The model was appreciated because it predicted bankruptcies with an accuracy of $72 \%$ two years before their occurrence, being further developed. The insolvency risk assessment has been the subject of numerous studies, and various models were developed based on the score method. The review of specialized articles highlighted both convergent (from the point of view of bankruptcy definition) and divergent (in terms of data collection procedures) opinions, concluding that the selection of prediction methods depends entirely on the research objective (Veganzones \& Severin, 2020).

In this context, the objectives of the research are: application of various techniques and methods such as Stepwise Least Squares Estimation through Forward method, canonical discriminant analysis and sensitivity analysis to a sample of 80 companies, for a period of four years, to measure the failure or financial health; verification of the robustness of the model through sensitivity analysis and multiple discriminant analysis. The companies were classified into financially stable and unstable. The paper was structured as follows: the next section represents a review of the literature; the third section contains a summary of the research methodology; the fourth section highlights the registered results, being followed by section five, conclusions. 


\section{Literature review}

Numerous studies have aimed to identify early models of insolvency forecasting, highlighting, for the first time, those developed in the '60s in the U.S.A. by Beaver (1966) and Altman (1968). Thus, Beaver analysed 30 financial rates at the level of 79 pairs of companies (failure/ non-failure), considering that the best discriminating factor was the working capital/debt ratio, followed by the net income/total assets ratio. Most research refers to multivariate models. In 1979, Conan and Holder developed another model for identifying the risk of bankruptcy, which facilitated the identification of companies with financial difficulties and financially sound. Taffler (1982) used discriminant analysis to analyse 46 bankrupt and 46 successful companies, being able to correctly predict bankruptcy with an occurrence probability of $97 \%$ one year before, $70 \%$ two years ahead, and $61 \%$ three years beforehand. Subsequently, Barniv and Agarwal (2002) considered that profitability, working capital position, financial risk, and liquidity are the four key dimensions in establishing the financial profile of a company. Gavurova et al. (2017) evaluated four models of bankruptcy prediction in the Slovak economy, in order to identify the optimal prediction model for it, finding that the use of the IN05 index (Neumaier \& Neumaierová, 2004) is superior to the Ohlson (1980) and Altman models. Also, Boda and Úradníček (2016), verified the applicability of the equation from the Altman model to the economic conditions in Slovakia, finding that the original wording and especially the revised one can be applied.

Grice and Ingram (2001) verified whether the Altman model has the same relevance in recent periods compared to the periods in which it was developed and tested, whether it is as useful for predicting the bankruptcy of non-manufacturing firms as for manufacturing, and whether it is useful for forecasting conditions of financial stress and bankruptcy, the results obtained being negative for the first two hypotheses and positive for the last hypothesis tested. Using the financial reports used by Altman, Odom and Sharda (1990) applied the neural calculation at the level of a sample of companies, their model allowing the correct identification of all companies (failed and non -failed). Moreover, the use of the neural network has influenced future research, Pan (2012) obtaining good convergence results by optimizing the neural network model of general regression. Methods based on machine learning and artificial intelligence have also been applied (Beyon \& Peel, 2001; Wang \& Wu, 2017). Good results in estimating the risk of bankruptcy were also obtained by combining the Borderline Synthetic Minority technique for data collection, feature extraction and classification and Stacked AutoEncoder (SAE) based on the Softmax classifier (Smiti \& Soui, 2020). Also, two novel prediction methods, called Bagged-pSVM and Boosted-pSVM, based on proportion support vector machine and ensemble learning strategies was proposed by Chen et al. (2020) to solving the problem of corporate bankruptcy prediction. Using approaches of support vector machines, artificial neural networks (ANN), nearest neighbor $\mathrm{k}$ and naive Bayesian classifier, Salehi et al. (2016) obtained results that demonstrated the efficiency of using the neural network method regarding the prediction effect. Sulub (2014) found that Altman's Z model for predicting the financial crisis is correct for multinational companies that failed at a predictive power of $70 \%$, and for those that failed with a predictive power of $55 \%$. Giacosa et al. (2016) used the models: discriminatory analysis (Altman, 1983), Taffler (1983) and logit analysis (Ohlson, 1980) for companies in Italy, finding that re-estimated models have 
a higher efficiency in making bankruptcy prediction compared to original models. Peyman et al. (2011) applied the Springate and Zmijewski models for bankruptcy forecasting, applying non-parametric binomial methods for data analysis, finding that there is a significant difference between them in terms of forecasting accuracy. Other researchers have also contributed to the original models by adding new variables and testing them in their economies for different sectors (Noga \& Adamowicz, 2021; Salehi \& Pour, 2016; Almamy et al., 2016; Ékes \& Koloszár, 2014; Karas et al., 2013; Hwang et al.; 2009 Ko et al., 2017; Ruxanda et al., 2018) or using a combination of several different methods of bankruptcy prediction (Salehi \& Shri, 2016). Bernard et al. (2007) considered social, financial and operational factors to classify companies and established a global model for performance evaluation. Other authors (Philosophov \& Philosophov, 2002) identified four important factors in predicting bankruptcy, and considered that these variables are much more efficient than the score function developed by Altman.

\section{Research methodology}

The research focused on identifying the most appropriate model for assessing the risk of bankruptcy in the Romanian business environment. Although du Jardin (2015) states that traditional bankruptcy prediction models perform only on short term (one year), one of the objectives of this study was to extend predictability to three years, while maintaining a high degree of accuracy. This was only possible by applying different methods and techniques of multidimensional data analysis. These helped to demonstrate the robustness of the identified model, because the more tests are applied to the original data, the more their relevance in the analysis can be confirmed.

\subsection{Data selection}

The research focused on identifying the most appropriate model for assessing the risk of bankruptcy in the Romanian business environment. As a result, a thorough selection of these data was necessary in order to prevent diminishing their predictability.

\section{Selection of companies}

The entire information base included in this study is obtained through data provided by the Bucharest Stock Exchange. Thus, the specificity of the analysis is given by the information specific to the companies that are listed on the Romanian capital market, from the manufacturing and extractive industry. The database was created by including 80 companies, out of which a percentage by $50 \%$ of them are in insolvency proceedings, in simplified insolvency proceedings or in bankruptcy. The percentage was determined by consulting the databases of the National Office of the Trade Register. Insolvency is a procedure that has diversified applicability, its characteristics being given by domestic legislative aspects, and thus different from one country to another. In general, insolvency is defined as the situation in which a firm's liabilities are higher than its assets (Altman \& Hotchkiss, 2006; Jackson \& Wood, 2013). When the company becomes insolvent, it has the obligation to take any measures leading to financial recovery and implicitly to the payment of creditors. In court, the only 
person responsible for the entry of a company into insolvency is the legal representative, because regardless of the circumstance, he/she must use the necessary resources to balance the economic and financial situation. Insolvency is a procedure that has diversified applicability, characteristic given by the legislative aspects specific to each country. In Romania, the insolvency procedure and its effects are as follows (Table 1).

The reason why companies that were in both bankruptcy and insolvency proceedings were included in the analysis is given by the financial difficulties they face, in both cases there are short, medium and long-term deficiencies in debt coverage (it was taken into account that insolvency occurs at an early stage, while bankruptcy manifests itself at an advanced stage, if the financial situation has not been balanced).

Although in the paper written by Altman (1968) on the forecast of corporate bankruptcy, certain maximum and minimum limits of turnover were imposed on the basis of which companies were included in the sample for analysis, the specificity of Romanian legislation related to insolvency proceedings and the simplified bankruptcy procedure required the addition of a new selection criterion. Thus, the value of total assets was a selection criterion, as real estate or movable property owned by a company is a defining element in determining the state of bankruptcy. The selected companies are part of the "medium and large" category, according to the criteria "total assets", and "turnover", used for the classification in various size categories, from a fiscal and accounting point of view.

In addition to the initial sample, two other samples were considered to be included in the analysis to determine the robustness of the bankruptcy risk predictability model. This test method was also applied by Noga and Adamowicz (2021). In this context, the first test sample comprises 25 companies in financial failure (defined similarly to the specifications for the companies in the initial sample), further marked with FC and 25 financially stable companies, marked with HC. The second test sample comprises a number of 50 healthy companies selected in order to best discriminate between the values of the score function.

\section{Selection of variables}

For each element of the sample population, data for the period 2015-2018 were collected. Based on these, 37 variables were calculated in the form of rates to be evaluated. The empirical literature was the basis for choosing the most relevant indicators for this study, such

Table 1. Insolvency proceedings - initiation and effects

\begin{tabular}{|l|l|l|l|}
\hline Possible situations & \multicolumn{1}{|c|}{ Actions } & \multicolumn{1}{|c|}{ Results } & \multicolumn{1}{c|}{ Effects } \\
\hline & $\begin{array}{l}\text { Reorganization } \\
\text { plan }\end{array}$ & $\begin{array}{l}\text { The plan is successful; all } \\
\text { debts are paid }\end{array}$ & $\begin{array}{l}\text { The company is coming out of } \\
\text { insolvency }\end{array}$ \\
\cline { 2 - 4 } $\begin{array}{l}\text { The company } \\
\text { enters into } \\
\text { insolvency }\end{array}$ & The plan is not successful & $\begin{array}{l}\text { The company goes bankrupt, } \\
\text { followed by its deregistration }\end{array}$ \\
\cline { 2 - 4 } & $\begin{array}{l}\text { No } \\
\text { reorganization } \\
\text { of the company } \\
\text { is required }\end{array}$ & All debts are paid & $\begin{array}{l}\text { The company becomes active in } \\
\text { the market again }\end{array}$ \\
\cline { 2 - 4 } & Not all debts are paid & $\begin{array}{l}\text { The company goes bankrupt, } \\
\text { followed by its deregistration }\end{array}$ \\
\cline { 2 - 4 } & $\begin{array}{l}\text { Simplified bankruptcy } \\
\text { procedure }\end{array}$ & $\begin{array}{l}\text { The company goes directly into } \\
\text { bankruptcy procedure }\end{array}$ \\
\hline
\end{tabular}


as Altman (1968), Beaver et al. (2005), Tinoco and Wilson (2013). Thus, the rates regarding the profitability, solvency, liquidity of the companies together with a set of other indicators, as well as two new rates that were considered relevant for the analysis, constituted the list of variables used in this study. Reducing the number of variables and keeping in the analysis only those that contain the most relevant information from a qualitative and quantitative point of view represented a complex process that involved the application of a series of tests and procedures. From the initial list of variables, five were selected, as together they provide the most remarkable volume of information for predicting the risk of corporate bankruptcy. In order to reach a final representation, the variables went through the following processes: (1) observing the statistical significance of each variable, independently, by applying alternative analyses; (2) observing the degree of association between variables; (3) assessing the predictability of models that included distinct sets of variables; (4) the reasoning of the analysis based on the empirical studies carried out so far and the elements of a theoretical nature.

The identification of the set of relevant variables in different studies was performed by applying the Stepwise Least Squares Estimation analysis through the Forwards method. Such a selection method requires the determination of the dependent variable and the independent variables. Bauweraerts (2016) and Valaskova et al. (2018) chose the use of bankruptcy as a dichotomous dependent variable. Therefore, this variable was created by coding the companies that were bankrupt or insolvent with the value of 1 and if they were financially stable with the value of 0 . In order to have a broader reasoning in the statistical analysis, the use of bankruptcy or insolvency as a dependent variable was used. The Stepwise-Forwards method is a combination of the Uni-directional-Forward method and the Backwards method as it introduces in the selection, in ascending order, the variables with the lowest $p$-value up to the highest. The selection of the most relevant and accurate predictors was made by imposing a $p$-value limit at 0.05 , including in the estimate only those variables that do not exceed this significance level. The Stepwise-Forwards routine is completed only when the $p$-value of the variables is greater than the specified limit.

Moreover, the predictors with the highest F values were taken into account. The selection procedure led to the identification of five indicators relevant to the analysis, X6 (debt to asset ratio), X8 (global solvency ratio), X31 (short-term debt ratio), X32 (global financial autonomy ratio) and X34 (Return on Assets). The Table 2 contains information related to tests of equality of group means. Wilks' Lambda is statistically significant, and the lower its value, the more relevant the predictive variable for the model. Thus, the variable X6 will have the largest contribution to the discriminant function, and $\mathrm{X} 8$ will be identified by the relatively small but, nevertheless, indispensable.

Table 2. Tests of equality of group means (source: authors' processing)

\begin{tabular}{|c|c|c|c|}
\hline Variables & Wilks' Lambda & F & Sig. $^{*}$ \\
\hline X6 & 0.436 & 68.517 & 0.000 \\
\hline X31 & 0.752 & 17.465 & 0.000 \\
\hline X32 & 0.679 & 25.006 & 0.000 \\
\hline X34 & 0.806 & 12.772 & 0.001 \\
\hline X8 & 0.933 & 3.820 & 0.056 \\
\hline
\end{tabular}

Note: ${ }^{\star}$ significant at the level 0.05 . 
As the variables individually meet the criteria for inclusion in the bankruptcy risk forecasting model, continuation of canonical discriminant analysis becomes possible.

\subsection{Canonical discriminant analysis}

In studies by Altman (1968), Taffler (1982), Memić (2015), Kliestik et al. (2018) and Rodrigues and Rodrigues (2018), discriminant analysis was successfully applied and continues to remain a useful study tool in determining the embeddedness of some individuals into certain groups. Applying the discriminant analysis results in an equation in the form of a linear combination (discriminant function) between the independent variables that will best discriminate between the existing groups of the dependent variable. The methodology for applying a discriminant analysis is in many ways like that of the regression model. We identify the regression analysis in this case under the following form:

$$
y=c_{0}+s c_{1} x r_{1, j t}+s c_{2} x r_{2, j t}+s c_{3} x r_{3, j t}+s c_{4} x r_{4, j t}+s c_{5} x r_{5, j t}+\varepsilon,
$$

where: $y$ is the dependent variable, $c_{0}$ is the constant, $s c_{1}, s c_{2}, s c_{3}$ and $s c_{4}$ represent the slope coefficients, $x r_{1}, x r_{2}, x r_{3}, x r_{4}$ and $x r_{5}$ financial ratios, $j$ the name of individuals, $t$ is the time and $\varepsilon$ represents the error term.

The main objective considered following the application of such an analysis is to identify the predictability of the bankruptcy risk assessment function. Thus, the discriminant analysis will be repeated three times, more precisely, the predictability of the function will be verified one year, two and three years before the occurrence of bankruptcy.

Before proceeding with the presentation of the model, it is necessary to evaluate the results of the summary of the canonical discriminant function that indicates the creditworthiness of the analysis. Table 3 contains a first result of the discriminant function and since the dependent variable was composed of only two categories, respectively failed companies and healthy companies, only one discriminant function was obtained. The eingenvalue indicates the variance of the dependent variable that is explained by the determined function. A value as high as possible of the eigenvalue is expected, and in this case a value of 2.522 indicates that the variance is very well explained by the function. Another aspect that is important in establishing the robustness of the analysis is given by the degree of association between the discriminant function and the dependent variable and is measured by the canonical correlation. A percentage of $84.60 \%$ indicates a strong degree of association, and, implicitly, a correct representation of the canonical discriminant function.

The results of a first test of the discriminant function are summarized in Table 4. To represent the relevance of the model, the $p$-value synthesizes in a favorable way the stability of the canonical discriminant function, this being statistically significant. Wilks' Lambda measures how well the obtained function separates the total sample into two groups. The value of Wilks' Lambda is 0.284 which indicates that the function has a very high ability to discriminate between the two groups, because the lower the value, the better the function separates the elements of the sample. The Chi-square association statistic tests whether the function average is equal for the two groups. The value of 63.578 contributes to the robustness of the analysis, suggesting that the discriminant function has a strong possibility of separating the two groups. 
Table 3. Eigenvalues (source: authors' processing)

\begin{tabular}{|c|c|c|c|c|}
\hline Function & Eigenvalue & $\%$ of variance & Cumulative $\%$ & Canonical correlation \\
\hline 1 & 2.522 & 100 & 100 & 0.846 \\
\hline
\end{tabular}

Tabel 4. Wilks' Lambda (source: authors' processing)

\begin{tabular}{|c|c|c|c|c|}
\hline Test of function & Wilks' Lambda & Chi-square & $\mathrm{df}$ & Sig.*$^{*}$ \\
\hline 1 & 0.284 & 63.578 & 5 & 0.000 \\
\hline
\end{tabular}

Note: ${ }^{\star}$ significant at the level 0.05 .

To consolidate the test results in Table 3, the distributions of the two groups are shown in Figure 1. First, the value of the standard deviation should be observed, which in group FC has a value of 1.575 (mean 2.80) and in the case of group HC has a value of 0.753 (mean 0.87). Thus, there is a slight dispersion of the values of the two groups around the mean. Second, it must be considered whether the values of the two overlap. According to the segmented line drawn, it can be concluded that the overlap of the values of the two groups is non-existent and the function of predicting the risk of bankruptcy discriminates very well.

The testing of the canonical discriminant function is finished by performing a sensitivity analysis of the values obtained. The scores appropriated to the FC group remained attributed to the same group, a similar situation encountered in the case of the HC group. No value migrated between the two groups (Figure 2).

The obtained model is able to have a high power of predictability as no degree of error in the assignment of values has been identified.

\section{Results and discussions}

In this approach for obtaining a bankruptcy or insolvency risk assessment model, a thorough selection of data is imperative in order not to diminish their predictability capacity. Both companies and indicators proposed for inclusion in the analysis went through a thorough selection based on theoretical and statistical aspects.

In this study, a mathematical model in the form of a linear regression to forecast the risk of bankruptcy or insolvency was obtained. Five variables that contain the largest amount of information were identifyied. For a more comprehensible representation, the original variables were redefined: X6 as $x r_{1}, \mathrm{X} 8$ as $x r_{2}, \mathrm{X} 31$ as $x r_{3}, \mathrm{X} 32$ as $x r_{4}$ and X34 as $x r_{5}$. Thus, the linear regression $R$ for estimating the risk of bankruptcy or insolvency took the following form:

$$
R=-4.019+0.066 x r_{1}-0.060 x r_{2}+0.844 x r_{3}+5.182 x r_{4}-0.952 x r_{5} .
$$

The indicators used are represented by: debt to asset ratio $\left(x r_{1}\right)$, global solvency ratio $\left(x r_{2}\right)$, short-term debt ratio $\left(x r_{3}\right)$, global financial autonomy ratio $\left(x r_{4}\right)$ and return on assets $\left(x r_{5}\right)$. In the literature on economic-financial analysis methodologies, these indicators are considered among the most relevant in assessing the financial position of a company. 


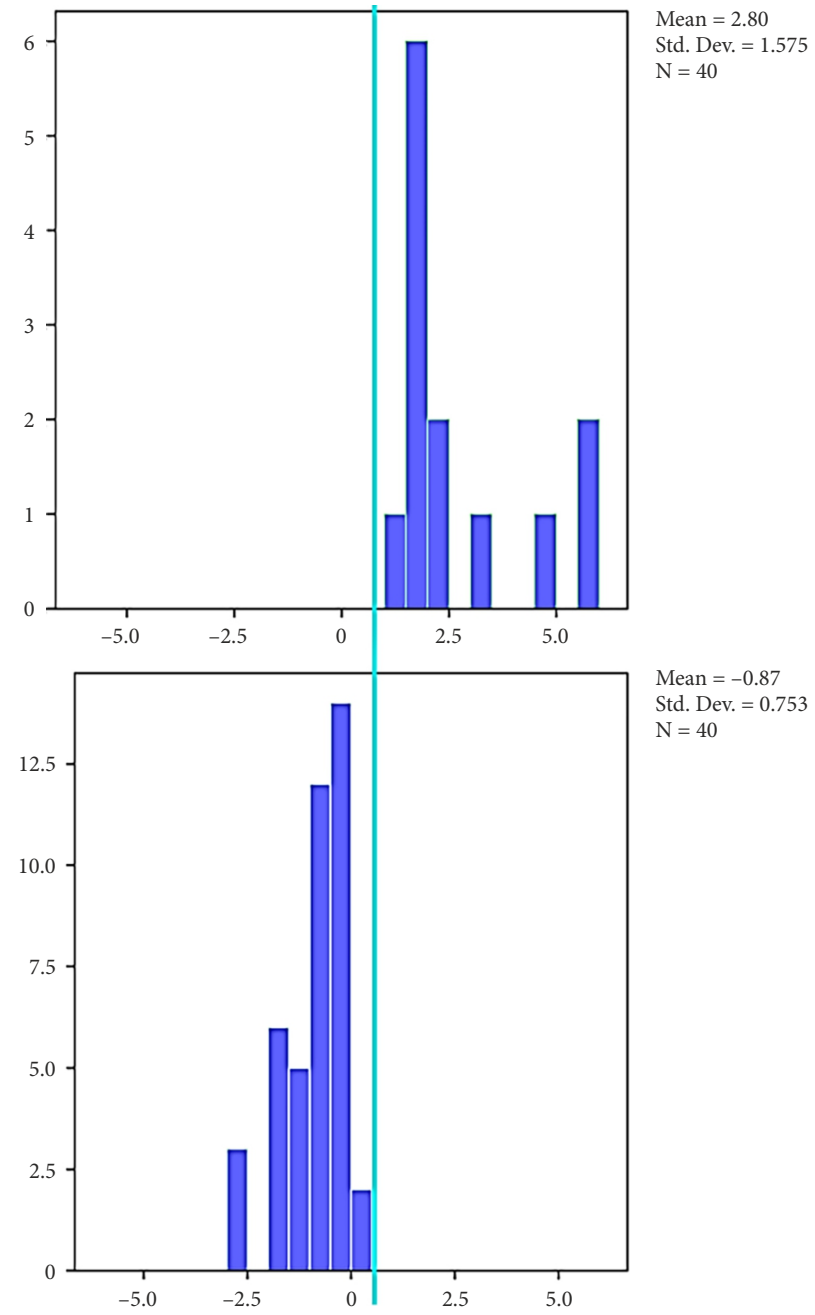

Figure 1. Histograms of groups (source: authors' processing)

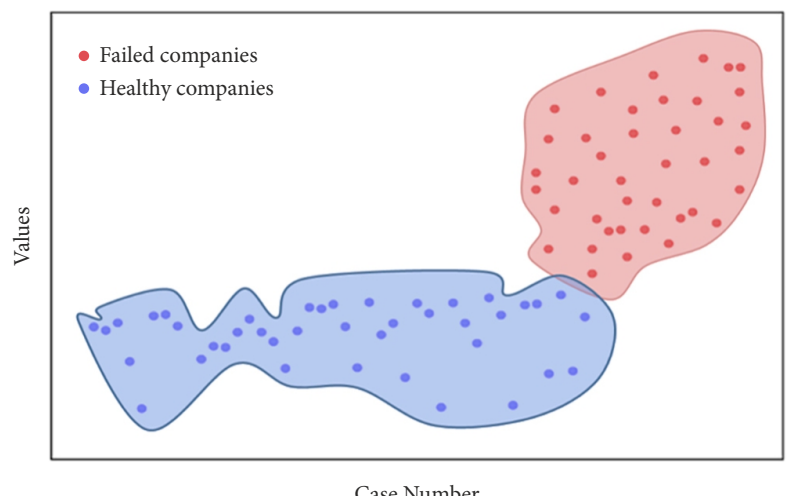

Figure 2. Casewise statistics (source: authors' processing) 
Furthermore, the results of the canonical discriminant analysis presented in the form of matrices showed the embeddedness of individuals into the initial groups, as well as their degree of accuracy. The failed group consists of 40 companies, and the healthy group consists of 40 companies. The discriminant analysis was applied to identify the correct classification of these companies. According to the results obtained following the application of the discriminant analysis, none of the $\mathrm{HC}$ migrated to FC. In the second case, 3 of the $40 \mathrm{FC}$ migrated to $\mathrm{HC}$. The accuracy of the model for predicting the risk of bankruptcy or insolvency a year in advance was very good. According to the existing data from Table 5, the model can predict the risk of bankruptcy or insolvency with an accuracy of $96.25 \%$. The type I error for HC is non-existent, and the type II error for FC is $18.90 \%$. Thus, an average error rate for this model applied one year prior to bankruptcy or insolvency is by $7.50 \%$.

The discriminant analysis was repeated to determine the correct general classification of companies in the second year before the occurrence of the state or risk of bankruptcy or insolvency. Following the information summarized in Table 6, none of the HC were assigned to the second group, and in the case of FC, 9 of them were assigned to the first group.

The prediction model obtained a remarkable percentage, the forecast two years prior to bankruptcy or insolvency being able to be predicted with an average percentage of $88.75 \%$. Although the forecasting degree is lower than in the first year, this decrease is normal, as the farther the time period is from the benchmark, the less defined the information. The percentage of type I error remains exactly as in the first year. The risk of bankruptcy or insolvency can be predicted at a percentage by $77.50 \%$. Although this comparison may be unjustified due to time, sample composition, or data processing techniques and methods, this percentage is higher than that identified by Altman (1968). The accuracy of the model proposed by him with two years prior to bankruptcy is by $72 \%$.

The results of the model predictability with three years before the onset of bankruptcy or insolvency are the same to those identified with two years before the onset of this state. However, none of the HC migrate to the second group, while in the case of FC, 9 of them migrate to the first group. The model prediction has an average percentage by $88.75 \%$. By applying the proposed model, the risk of bankruptcy or insolvency can be identified three years earlier in a proportion by $77.5 \%$ in the case of the group of companies that have an unfavourable financial situation (Table 7).

Following the presentation of the discriminant analysis results, it can be stated that the long-term accuracy of the bankruptcy or insolvency risk predictability model is very high. The inclusion of the five financial indicators in such a model can provide much higher quality information than analysed individually. Based on these results, the bankruptcy or insolvency risk prediction function can be used for identifying it up to three years in advance. In this context, identifying the likelihood of occurrence of the risk of bankruptcy or insolvency with three years in advance may be a sufficient period for the directors or board of directors of a company to take the necessary measures to avoid or improve this situation. 
Table 5. Model prediction for one year prior to bankruptcy or insolvency (source: authors' processing)

\begin{tabular}{|l|c|c|c|c|}
\hline & Correct number & Correct percent & Error percent & Total group members \\
\hline Type I error & 40 & 100.00 & 0.00 & 40 \\
\hline Type II error & 37 & 92.50 & 7.50 & 40 \\
\hline Correctly predicted & 77 & 96.25 & 7.50 & 80 \\
\hline
\end{tabular}

Table 6. Model prediction for two years prior to bankruptcy or insolvency (source: authors' processing)

\begin{tabular}{|l|c|c|c|c|}
\hline & Correct number & Correct percent & Error percent & Total group members \\
\hline Type I error & 40 & 100.00 & 0.00 & 40 \\
\hline Type II error & 31 & 77.50 & 22.50 & 40 \\
\hline Correctly predicted & 71 & 88.75 & 22.50 & 80 \\
\hline
\end{tabular}

Table 7. Model prediction for three years prior to bankruptcy or insolvency (source: authors' processing)

\begin{tabular}{|l|c|c|c|c|}
\hline & Correct number & Correct percent & Error percent & Total group members \\
\hline Type I error & 40 & 100.00 & 0.00 & 40 \\
\hline Type II error & 31 & 77.50 & 22.50 & 40 \\
\hline Correctly predicted & 71 & 88.75 & 22.50 & 80 \\
\hline
\end{tabular}

\subsection{Cut off points and confidence intervals}

Establishing confidence intervals following the identification of a bankruptcy risk predictability model has created several divergences in the literature. Various methods for determining risk areas have been debated and analysed with the intention of minimizing the risk of misclassification due to erroneous determination of cut-off points. Altman (1968) and Deakin (1972) determined the cut-off points at the limits of type I and type II probability errors to minimize the number of misclassifications. Hsieh (1993) proposes a model for determining the cut off point based on Bayes' theorem in order to minimize error costs. Lachenbruch (1967) used a method called U-technique. This method is performed by retaining an observation at a certain time to be classified after estimating a multivariate function with the other observations, the procedure being repeated until all observations are classified and validated based on an inter-temporal division (Barniv et al., 2002). Taking into account the models for determining the cut off points, as well as the accuracy of the confidence intervals, this study aims to determine with the highest possible probability the bankruptcy risk. Thus, the limits of type I and type II probability errors will be taken into account for establishing optimal cut off points, as well as relevant confidence intervals. The target group in this type of analysis is represented by companies that were misclassified in the three years prior to bankruptcy. For these companies the $\mathrm{R}$ score was calculated and its minimum and maximum values were included in Table 8 . By applying such a procedure, it was possible to easily identify the cut off points. 
Table 8. Misclassification limits (source: authors' processing)

\begin{tabular}{|c|c|c|c|}
\hline \multirow{2}{*}{ Years } & \multicolumn{2}{|c|}{ Limit value } & Cut off points extreme limits \\
\hline \multirow{2}{*}{1} & $\min$ & -0.024 & $\min$ \\
\cline { 2 - 4 } & $\max$ & 0.467 & -0.466 \\
\hline \multirow{2}{*}{2} & $\min$ & -0.466 & $\max$ \\
\cline { 2 - 4 } & $\max$ & 0.374 & 0.467 \\
\cline { 2 - 4 } 3 & $\min$ & -0.090 & \multirow{2}{*}{0.218} \\
\hline
\end{tabular}

The determination of the confidence intervals was performed with great precision, due to the applied procedure. The confidence interval between -0.466 and 0.467 will be called as the uncertainty interval, medium risk of bankruptcy or insolvency. Those companies that have obtained an $R$ score greater than 0.467 are considered bankrupt or with a high risk of bankruptcy, and the confidence interval will be determined as risk interval. At the opposite pole will be the companies considered financially stable and placed in the confidence interval, where the $R$ value obtained is lower than -0.466 .

\subsection{Testing the prediction model}

The next step in this analysis is to test the bankruptcy or insolvency risk prediction model based on two distinct samples. Thus, the first sample considered consists of $25 \mathrm{FC}$ and $25 \mathrm{HC}$ respectively. The reason why this sample is composed of equal elements specific to the two groups is to test the efficiency of the canonical discriminant function when it is actually put into practice, its results being systematized in Table 9. Thus, for the 50 companies the score was calculated, risk, and the confidence interval. In the year prior to the occurrence of bankruptcy or insolvency, the score of the canonical discriminatory function indicated that $22 \mathrm{HC}$ are declared financially stable and 3 of them are attributed to the uncertainty interval. In the case of CF, 21 of them are attributed to the bankruptcy or insolvency area, 1 is attributed to the insecurity area, and 3 of them are considered financially stable. Based on the companies that migrated to the other group, except for the uncertainty interval, the type I error and the type II error were calculated. In this context, in the first year prior to bankruptcy or insolvency, the type I error is non-existent and the type II error is by $12.00 \%$. In the second year prior to the occurrence of bankruptcy or insolvency, the result of the $\mathrm{HC}$ group is similar to that in the first year. In the case of the FC group, the situation is different, as out of the 25 companies that should be in the area of bankruptcy or insolvency, 4 have migrated to the area of companies that are financially stable. Thus, the type II error increases by $4 \%$ compared to the first year. In the last year under analysis, the results will change only in the case of the HC group. The type I error is for the first time present in a percentage by $4 \%$, as a company has migrated to the area of bankruptcy or insolvency.

The second test sample comprises a number of 50 financially stable companies, selected in order to identify the power of discrimination of the score function in case of its application on a single category. Table 10 also indicates a correct classification in the case of the sample 
composed only of financially stable companies. In the first and second year prior to the occurrence of bankruptcy or insolvency 9 of the companies migrated within the uncertainty interval, and in the last year under analysis they migrated 11.

According to the results obtained after testing the canonical discriminant function, it can be concluded that both the prediction model and the cut-off points of the confidence interval are robust and can have concrete applicability. The results obtained are in accordance to those of other studies. Thus, Jabeur (2017) used Logistic Regression and Partial Least Squares Logistic Regression to build a bankruptcy risk forecasting model. The results indicated that the model has a short-term applicability (one year). The predictability with three years before the occurrence of the risk of bankruptcy was of $70.50 \%$. In this study the average percentage obtained was $88.75 \%$. Also, Kostrzewska et al. (2016) used logit analysis to identify the two groups and, unlike the present study, did not get as satisfactory results. Noga and Adamowicz (2021) state that multiple discriminant analysis is likely to be much more effective than Logistic regression. Unlike those mentioned above, Takahashi et al. (1984) and Telipenko (2015) used the analysis of key components to predict the risk of bankruptcy of companies.

Businesses have always played a key role in the economic and social life of a country. They will always contribute to the development of society through mandatory levies for the state budget, through the extensive use of human resources, but also through the know-how element important for the evolution in a specific field of activity. As in any market economy, enterprises are an indispensable constituent of the economy through the production of goods, the execution of works or the provision of services. In this context, there was a

Table 9. First sample test (source: authors' processing)

\begin{tabular}{|c|c|c|c|c|c|}
\hline \multirow{2}{*}{$\begin{array}{c}\text { Years prior } \\
\text { to failure }\end{array}$} & $\begin{array}{c}\text { Groups } \\
(\mathrm{N}=25 \mathrm{HC}, \\
\mathrm{N}=25 \mathrm{FC})\end{array}$ & $\begin{array}{c}\text { Financially } \\
\text { stable }\end{array}$ & \begin{tabular}{c} 
Uncertainty interval \\
\cline { 3 - 6 }
\end{tabular} & $\begin{array}{c}\text { Bankruptcy or } \\
\text { insolvency }\end{array}$ & $\begin{array}{c}\text { Type I and } \\
\text { type II error }\end{array}$ \\
\hline \multirow{2}{*}{1} & HC & 22 & from -0.466 to 0.467 & $>0.467$ & $0.00 \%$ \\
\cline { 2 - 6 } & FC & 3 & 3 & 21 & $12.00 \%$ \\
\hline \multirow{2}{*}{2} & HC & 23 & 2 & 0 & $0.00 \%$ \\
\cline { 2 - 6 } & FC & 4 & 0 & 21 & $16.00 \%$ \\
\hline \multirow{2}{*}{3} & HC & 21 & 3 & 1 & $4.00 \%$ \\
\cline { 2 - 6 } & FC & 4 & 0 & 21 & $16.00 \%$ \\
\hline
\end{tabular}

Table 10. Second sample test (source: authors' processing)

\begin{tabular}{|c|c|c|c|c|c|}
\hline \multirow{2}{*}{$\begin{array}{c}\text { Years prior } \\
\text { to failure }\end{array}$} & $\begin{array}{c}\text { Groups } \\
(\mathrm{N}=30 \mathrm{HC})\end{array}$ & $\begin{array}{c}\text { Financially } \\
\text { stable }\end{array}$ & Uncertainty interval & $\begin{array}{c}\text { Bankruptcy or } \\
\text { insolvency }\end{array}$ & $\begin{array}{c}\text { Type I and } \\
\text { type II error }\end{array}$ \\
\cline { 3 - 6 } & $<-0.466$ & from -0.466 to 0.467 & $>0.467$ & $0.00 \%$ \\
\hline 1 & HC & 41 & 9 & 0 & $0.00 \%$ \\
\hline 2 & HC & 41 & 9 & 0 & $0.00 \%$ \\
\hline 3 & HC & 39 & 11 & 0 & 0 \\
\hline
\end{tabular}


particular interest in predicting bankruptcy, bringing to the horizon of economic knowledge possibilities through which this economic situation of the company can be identified a coupe of years before the decline. Although there are also accounting methods to identify the risk of bankruptcy by analyzing the solvency of the patrimony but also of the working capital that can demonstrate whether or not the company is in a state of equilibrium, they offer the possibility of a limited interpretation in time and space. In this context, the results obtained can be a useful tool for companies' managers in predicting the risk of bankruptcy.

\section{Conclusions}

Financial management plays an important role in terms of its applicability within a company. This provides relevant information regarding the risk exposure, and the longer and more relevant the predictability period, the better the risks related to the insolvency of a company or in the worst case the appearance of the state of bankruptcy can be ameliorated. In this context, the development of a bankruptcy risk forecasting model has become a widely debated topic in the empirical literature. This was also due to the financial instruments used which require a complex calculation analysis to determine the exposure to several risks, from operational risk to reputational risk. Incorporating the most relevant information obtained from the analysis of economic-financial indicators and developing a model for assessing the risk of bankruptcy of companies can be considered the easiest way to predict future financial statements.

This study contributed not only to the development of a bankruptcy forecasting model, but also to insolvency, unlike other studies that analyzed only one possible situation. The reason why insolvency forecasting is very important is given by the interdependence between the two financial statements of a company. When a company is in a state of insolvency, the possibility of it going bankrupt due to the inability to comply with the financial recovery plan is extremely high. In addition, another classification variable (asset value) was introduced, with a much lower level of error rates.

Moreover, it can be stated that the $R$ function of bankruptcy or insolvency risk predictability is superior to that identified by other authors, because the variables used contain an even greater amount of information, and its predictability three years prior to bankruptcy has an accuracy by $29.5 \%$ higher. This study serves a wide range of users, from directors and creditors, to investors, bankers or loan officers, as it can be used by performing a small number of calculations, providing a very high degree of accuracy. One aspect to consider is the limitations that the application of such a model might have. The specificity of national legislation, as well as other aspects related to the market in which a company operates, can influence the probability of predicting the risk of bankruptcy or insolvency. We suggest that the model be adjusted if it is to be applied to companies that are under the legal jurisdiction of another country. Obviously, the research carried out has certain limitations. Thus, the availability of data did not allow the study to be conducted at the level of a larger sample. Also, future research requires relating to the macroeconomic conditions that affect the evolution of financial variables used in predicting bankruptcy. Taxes, corporate tax incentives, financial policies and practices, as well as several other economic factors can cause a wide range of 
discrepancies when trying to achieve an interstate differentiation between companies that are financially stable and those that are experiencing difficulties. All these, and the development of a complex model that is generally accepted through the use of predictors from this model for all the categories of companies (small, medium and large) could represent new directions of study in this niche.

\section{Acknowledgements}

Project financed by Lucian Blaga University of Sibiu \& Hasso Plattner Foundation research grants LBUS-IRG-2020-06.

\section{Author contributions}

ADV and GD conceived the study and were responsible for the design and development of the data analysis. GD, ADV, TDM, DDD and DD were responsible for data collection and analysis. AVD, GD and TDM were responsible for data interpretation. ADV and GD wrote the first draft of the article; TDM, DDD and DD was responsible for resources, visualization and validation.

\section{Disclosure statement}

We declare that we don't have any competing financial, professional, or personal interests from other parties.

\section{References}

Almamy, J., Aston, J., \& Ngwa, L. (2016). An evaluation of Altman's Z-score using cash flow ratio to predict corporate failure amid the recent financial crisis: Evidence from the UK. Journal of Corporate Finance, 36, 278-285. https://doi.org/10.1016/j.jcorpfin.2015.12.009

Altman, E. I. (1968). Financial ratios, discriminant analysis and the prediction of corporate bankruptcy. The Journal of Finance, 4(23), 589-609. https://doi.org/10.1111/j.1540-6261.1968.tb00843.x

Altman, E. I. (1983). Corporate financial distress. Wiley Interscience.

Altman, E. I., \& Hotchkiss, E. (2006). Corporate financial distress and bankruptcy. John Wiley \& Sons. https://doi.org/10.1002/9781118267806

Barniv, R., Agarwal, A., \& Leach, R. (2002). Predicting bankruptcy resolution. Journal of Business Finance \& Accounting, 29(3-4), 497-520. https://doi.org/10.1111/1468-5957.00440

Bauweraerts, J. (2016). Predicting bankruptcy in private firms: Towards a stepwise regression procedure. International Journal of Financial Research, 7(2), 147-153. https://doi.org/10.5430/ijfr.v7n2p147

Beaver, W. H. (1966). Financial ratios as prediction of failure. Journal of Accounting Research, 3(71), 150-161. https://doi.org/10.2307/2490171

Beaver, W. H., McNichols, M. F., \& Rhie, J. W. (2005). Have financial statements become less informative? Evidence from the ability of financial ratios to predict bankruptcy. Review of Accounting Studies, 10(1), 93-122. 
Beynon, M., \& Peel, M. (2001). Variable precision rough set theory and data discretization: An application to corporate failure prediction. Omega, 29(6), 561-576.

https://doi.org/10.1016/S0305-0483(01)00045-7

Bernard, A., Redding, S., \& Schott, P. (2007). Comparative advantage and heterogeneous firms. Review of Economic Studies, 74(1), 31-66. https://doi.org/10.1111/j.1467-937X.2007.00413.x

Boda, M., \& Úradníček, V. (2016). The portability of altman's Z-score model to predicting corporate financial distress of Slovak companies. Technological and Economic Development of Economy, 22(4), 532-553. https://doi.org/10.3846/20294913.2016.1197165

Chen, Z., Chen, W., \& Shi, Y. (2020). Ensemble learning with label proportions for bankruptcy prediction. Expert Systems with Applications, 146, 113-155. https://doi.org/10.1016/j.eswa.2019.113155

Conan, J., \& Holder, M. (1979). Variables explicatives de performances et contrôle de gestion dans les PMI [Thèse de Doctorat en sciences de gestion]. Université de Paris IX, Paris.

Deakin, E. (1972). A discriminant analysis of predictors of business failure. Journal of Accounting Research, 10, 167-179. https://doi.org/10.2307/2490225

$\mathrm{du}$ Jardin, P. (2015). Bankruptcy prediction using terminal failure processes. European Journal of Operational Research, 242(1), 286-303. https://doi.org/10.1016/j.ejor.2014.09.059

Ékes, K. S., \& Koloszár, L. (2014). The efficiency of bankruptcy forecast models in the Hungarian SME Sector. Journal of Competitiveness, 6(2), 56-73. https://doi.org/10.7441/joc.2014.02.05

Garškienè, A., \& Garškaite, K. (2004). Enterprise bankruptcy in Lithuania. Journal of Business Economics and Management, 5(1), 51-58. https://doi.org/10.3846/16111699.2004.9636068

Gavurova, B., Packova, M., Misankova, M., \& Smrcka, L. (2017). Predictive potential and risks of selected bankruptcy prediction models in the Slovak business environment. Journal of Business Economics and Management, 18(6), 1156-1173. https://doi.org/10.3846/16111699.2017.1400461

Giacosa, E., Halili, E., Mazzoleni, A., Teodori, C., \& Veneziani, M. (2016). Re-estimation of company insolvency prediction models: survey on Italian manufacturing companies. Corporate Ownership and Control, 14(1), 159-174. https://doi.org/10.22495/cocv14i1c1p1

Grice, J. S., \& Ingram, R. W. (2001). Tests of the generalizability of Altman's bankruptcy prediction model. Journal of Business Research, 54(1), 53-61. https://doi.org/10.1016/S0148-2963(00)00126-0

Hsieh, S. J. (1993). A note on the optimal cutoff point in bankruptcy prediction models. Journal of Business Finance \& Accounting, 20(3), 457-464. https://doi.org/10.1111/j.1468-5957.1993.tb00268.x

Hwang, R. C., Cheng, K. F., \& Lee, C. F. (2009). On multiple-class prediction of issuer credit ratings. Applied Stochastic Models in Business and Industry, 25(5), 535-550. https://doi.org/10.1002/asmb.735

Jabeur, S. B. (2017). Bankruptcy prediction using partial least squares logistic regression. Journal of Retailing and Consumer Services, 36, 197-202. https://doi.org/10.1016/j.jretconser.2017.02.005

Jackson, R. H. G., \& Wood, A. (2013). The performance of insolvency prediction and credit risk models in the UK: A comparative study. The British Accounting Review, 45(3), 183-202. https://doi.org/10.1016/j.bar.2013.06.009

Karas, M., Reznakova, M., Bartos, V., \& Zinecker, M. (2013). Possibilities for the application of the Altman model within the Czech Republic. In Recent Researches in Law Science and Finances (pp. 203-207). http://www.wseas.us/e-library/conferences/2013/Chania/ICFA/ICFA-30.pdf

Kliestik, T., Vrbka, J., \& Rowland, Z. (2018). Bankruptcy prediction in Visegrad group countries using multiple discriminant analysis. Equilibrium. Quarterly Journal of Economics and Economic Policy, 13(3), 569-593. https://doi.org/10.24136/eq.2018.028

Ko, Y. C., Fujita, H., \& Li, T. (2017). An evidential analysis of Altman Z-score for financial predictions: Case study on solar energy companies. Applied Soft Computing, 52, 748-759.

https://doi.org/10.1016/j.asoc.2016.09.050 
Kostrzewska, J., Kostrzewski, M., Pawelek, B., \& Galuszka, K. (2016). The classical and Bayesian logistic regression in the research on the financial standing of enterprises after bankruptcy in Poland. In Proceedings of the 10th professor Aleksander Zelias international conference on modelling and forecasting of socio-economic phenomena (pp. 72-81). Foundation of the Cracow University of Economics.

Lachenbruch, P. A. (1967). An almost unbiased method of obtaining confidence levels for the probability of misclassification in discriminant analysis. Biometrics, 23, 639-645. https://doi.org/10.2307/2528418

Levratto, N. (2013). From failure to corporate bankruptcy: a review. Journal of Innovation and Entrepreneurship, 2, 20. https://doi.org/10.1186/2192-5372-2-20

Memić, D. (2015). Assessing credit default using logistic regression and multiple discriminant analysis: Empirical evidence from Bosnia and Herzegovina. Interdisciplinary Description of Complex Systems: INDECS, 13(1), 128-153. https://doi.org/10.7906/indecs.13.1.13

Neumaier, I., \& Neumaierová, I. (2004). Index IN 05. In P. Červinek (Ed.), Sborník příspěvků mezinárodní vědecké konference „Evropské fi nanční systémy“ (pp. 143-148). Ekonomickosprávní fakulta Masarykovy University.

Noga, T., \& Adamowicz, K. (2021). Forecasting bankruptcy in the wood industry. European Journal of Wood Products, 79, 735-743. https://doi.org/10.1007/s00107-020-01620-y

Odom, M. D., \& Sharda, R. (1990). A neural network model for bankruptcy prediction. Proceedings of the International Joint Conference on Neural Networks, 2, 163-167.

https://doi.org/10.1109/IJCNN.1990.137710

Ohlson, J. (1980). Financial ratio and the probabilistic prediction of bankruptcy. Journal of Accounting Research, 18(1), 109-131. https://doi.org/10.2307/2490395

Pan, W. (2012). A new Fruit Fly Optimization Algorithm: Taking the financial distress model as an example. Knowledge-Based Systems, 26, 69-74. https://doi.org/10.1016/j.knosys.2011.07.001

Peyman, I., Mehdi, M.-J., \& Petro, S. (2011). A study of the application of springate and zmijewski bankruptcy prediction models in firms accepted in Tehran Stock Exchange. Australian Journal of Basic and Applied Sciences, 5(11), 1546-1550.

Philosophov, L., \& Philosophov, V. (2002). Corporate bankruptcy prognosis: An attempt at a combined prediction of the bankruptcy event and time interval of its occurrence. International Review of Financial Analysis, 11(3), 375-406. https://doi.org/10.1016/S1057-5219(02)00081-9

Rodrigues, L., \& Rodrigues, L. (2018). Economic-financial performance of the Brazilian sugarcane energy industry: An empirical evaluation using financial ratio, cluster and discriminant analysis. Biomass and Bioenergy, 108, 289-296. https://doi.org/10.1016/j.biombioe.2017.11.013

Ruxanda, G., Zamfir, C., \& Muraru, A. (2018). Predicting financial distress for Romanian companies. Technological and Economic Development Economy, 24(6), 2318-2337. https://doi.org/10.3846/tede.2018.6736

Salehi, M., \& Pour, M. D. (2016). Bankruptcy prediction of listed companies on the Tehran Stock Exchange. International Journal of Law and Management, 58(5), 545-561. https://doi.org/10.1108/IJLMA-05-2015-0023

Salehi, M., \& Shri, M. M. (2016). Different bankruptcy prediction patterns in an emerging economy: Iranian evidence. International Journal of Law and Management, 58(3), 258-280. https://doi.org/10.1108/IJLMA-05-2015-0022

Salehi, M., Shri, M. M., \& Bolandraftar, M. (2016). Predicting corporate financial distress using data mining techniques: An application in Tehran Stock Exchange. International Journal of Law and Management, 58(2), 216-230. https://doi.org/10.1108/IJLMA-06-2015-0028 
Schielke, H. J., Fishman, J. L., Osatuke, K., \& Stiles, W. B. (2009). Creative consensus on interpretations of qualitative data: The Ward method. Psychotherapy Research, 19(4-5), 558-565. https://doi.org/10.1080/10503300802621180

Smiti, S., \& Soui, M. (2020). Bankruptcy prediction using deep learning approach based on Borderline SMOTE. Information Systems Frontiers, 5(22), 1067-1083. https://doi.org/10.1007/s10796-020-10031-6

Sulub, S. A. (2014). Testing the predictive power of Altman's revised Z' model: the case of 10 multinational companies. Research Journal of Finance and Accounting, 5(21), 174-184.

Taffler, R. J. (1982). Forecasting company failure in the UK using discriminant analysis and financial ratio data. Journal of the Royal Statistical Society: Series A (General), 145(3), 342-358. https://doi.org/10.2307/2981867

Taffler, R. J. (1983, March 22-24). The Z-Score approach to measuring company solvency. The Accountant's Magazine.

Takahashi, K., Kurokawa, Y., \& Watase, K. (1984). Corporate bankruptcy prediction in Japan. Journal of Banking \& Finance, 8(2), 229-247. https://doi.org/10.1016/0378-4266(84)90005-0

Telipenko, E. V., Zakharova, A. A., \& Sopova, S. P. (2015). Forecasting risk of bankruptcy for machine-building plants. IOP Conference Series: Materials Science and Engineering, 19(1), 012066. https://doi.org/10.1088/1757-899X/91/1/012066

Tinoco, M. H., \& Wilson, N. (2013). Financial distress and bankruptcy prediction among listed companies using accounting, market and macroeconomic variables. International Review of Financial Analysis, 30, 394-419. https://doi.org/10.1016/j.irfa.2013.02.013

Valaskova, K., Kliestik, T., Svabova, L., \& Adamko, P. (2018). Financial risk measurement and prediction modelling for sustainable development of business entities using regresision analysis. Sustainability, 10(7), 2144. https://doi.org/10.3390/su10072144

Veganzones, D., \& Severin, E. (2020). Corporate failure prediction models in the twenty-first century: a review. European Business Review, 33(2), 204-226. https://doi.org/10.1108/EBR-12-2018-0209

Wang, L., \& Wu, C. (2017). Business failure prediction based on two-stage selective ensemble with manifold learning algorithm and kernel-based fuzzy self-organizing map. Knowledge-Based Systems, 121, 99-110. https://doi.org/10.1016/j.knosys.2017.01.016 